\title{
AIDS survival and progression in black Africans living in south London, 1986-1994
}

\author{
Nicola Low, Katie Paine, Rebecca Clark, Meera Mahalingam, Anton L Pozniak
}

Objectives: To describe the rate of progression to AIDS and survival following AIDS diagnosis in HIV-infected Africans living in London. To identify factors influencing progression and outcome of disease.

Design: Retrospectively constructed prevalent cohort.

Setting: Outpatient clinic population, London.

Subjects: HIV-infected individuals of African origin presenting between January 1986 and October 1994.

Main outcome measures: AIDS indicator illness; cumulative survival probabilities to AIDS diagnosis and from AIDS diagnosis to death; rate of progression to AIDS.

Results: Ninety six patients (57 women) provided 166 person years of follow up. Median CD4 lymphocyte count at presentation was $205\left(90 \%\right.$ range 20-577) $\times 10^{6} / 1$. Kaplan-Meier estimates of the proportion ( $95 \%$ confidence interval) of patients developing AIDS from the time of enrolment were 18 ( 9 to 27$) \%$ at 12 months and 44 (30 to 58 )\% at 36 months. Only CD4 count at HIV diagnosis was independently associated with a faster rate of progression to AIDS (adjusted relative hazard 9.18, 95\% confidence interval 2.84 to $29 \cdot 67, \mathrm{p}<0.001$ ). The proportion $(95 \%$ confidence interval) surviving following AIDS diagnosis was estimated to be .73 (55 to 91$) \%$ at 12 months and 25 (0 to 52$) \%$ at 36 months.

Conclusions: HIV-infected people of sub-Saharan African origin living in London present with advanced disease. When compared with published studies, their survival experience is comparable to that observed in HIV-infected individuals born in developed countries.

(Genitourin Med 1996;72:12-16)

Keywords: HIV infection/epidemiology; AIDS; survival analysis; Africa; migration

\section{Introduction}

Observational studies ${ }^{12}$ and mathematical mod$\mathrm{els}^{3}$ of human immunodeficiency virus (HIV) infected individuals in Africa suggest that progression from asymptomatic disease to acquired immune deficiency syndrome (AIDS) and death are faster than in developed countries. This may be due to poverty ${ }^{4}$ and malnutrition, limited access to medical care, ${ }^{5}$ a different spectrum of AIDS indicator illnesses (AII), ${ }^{67}$ concurrent debilitating infections, different viral strains, or to a combination of these factors.

Africans who live in Europe and are found to be HIV antibody positive come from diverse countries and backgrounds. Whether or not their survival with HIV disease is more similar to that seen in the country of origin or country of residence has not been determined, but such information could provide epidemiological clues to factors influencing disease progression. We present here the analysis of a retrospectively constructed prevalent cohort of black Africans attending an HIV outpatient clinic in London to describe, progression to AIDS, risk factors for development of AIDS and survival following a diagnosis of AIDS. Comparisons are made with studies of the survival experience of HIV-infected individuals born in Europe and North America.

\section{Subjects and methods}

We attempted to include all patients from subSaharan Africa who had HIV infection diagnosed between January 1986 and October
1994. By manual inspection, all case records of HIV positive patients were scanned for documentary evidence of black African ethnic origin in the clinical history or from the patient registration form, where ethnicity is selfdefined from a specified list of options.

Information retrieved from case notes included: demography; dates and details of AIDS indicator illnesses and duration of follow up. We considered pulmonary tuberculosis as an $\mathrm{AII},{ }^{8}$ irrespective of the date of presentation, in order to maintain internal consistency. Serial CD4 lymphocyte counts were measured by flow cytometry to a lower limit of $20 \times 10^{6} / 1$, below which the absolute count was not reported. Follow up data on each patient were reviewed until death or censored at the last documented visit, or at 31 October 1994 if the patient was alive at that date.

\section{Statistical analysis}

Data were analysed using SPSS for Windows (version 5.01). Comparisons between groups were made using a two sample $t$-test or, for non-normally distributed data, a MannWhitney $U$ test. All $p$ values are two-tailed. Decline in CD4 lymphocyte count was calculated by linear regression for each patient with more than three counts greater than $20 \times$ $10^{6} / 1$ during the follow up period. A weighted mean rate of decline was then calculated. The probability of survival to clinical end points of AIDS and death was described using Kaplan- 
Table 1 Selected characteristics of black African patients with HIV infection

\begin{tabular}{|c|c|c|c|}
\hline Characteristic & & $\begin{array}{l}\text { Number* } \\
(\text { total }=96)\end{array}$ & $\%$ \\
\hline Sex & $\begin{array}{l}\text { Female } \\
\text { Male }\end{array}$ & $\begin{array}{l}57 \\
39\end{array}$ & 59 \\
\hline Age (years) & $\begin{array}{l}15-24 \\
25-29 \\
30-34 \\
\geqslant 35\end{array}$ & $\begin{array}{l}24 \\
30 \\
22 \\
20\end{array}$ & $\begin{array}{l}25 \\
31 \\
23 \\
21\end{array}$ \\
\hline Region of origin & $\begin{array}{l}\text { East Africa } \\
\text { Central Africa } \\
\text { Southern Africa } \\
\text { West Africa } \\
\text { Other }\end{array}$ & $\begin{array}{r}61 \\
10 \\
11 \\
7 \\
7\end{array}$ & $\begin{array}{r}64 \\
10 \\
11 \\
7 \\
7\end{array}$ \\
\hline $\begin{array}{l}\text { Time spent in Europe before } \\
\text { HIV diagnosis }\end{array}$ & $\begin{array}{l}0-5 \text { months } \\
6-23 \text { months } \\
24-59 \text { months } \\
\geqslant 60 \text { months } \\
\text { Not recorded }\end{array}$ & $\begin{array}{l}21 \\
17 \\
16 \\
18 \\
24\end{array}$ & $\begin{array}{l}22 \\
18 \\
17 \\
19 \\
25\end{array}$ \\
\hline Follow up status at $31 / 10 / 94$ & $\begin{array}{l}\text { Ongoing follow up } \\
\text { Returned to Africa } \\
\text { Died } t \\
\text { Not seen for }>1 \text { year }\end{array}$ & $\begin{array}{r}60 \\
4 \\
16 \\
16\end{array}$ & $\begin{array}{r}63 \\
4 \\
17 \\
17\end{array}$ \\
\hline Baseline CD4 lymphocyte count & $\begin{array}{c}0-49 \times 10^{6 / 1} \\
50-199 \times 10^{6} 1 \\
200-399 \times 10^{6} / 1 \\
\geqslant 400 \times 10^{6 / 1} \\
\text { Not recorded }\end{array}$ & $\begin{array}{l}19 \\
22 \\
27 \\
16 \\
12\end{array}$ & $\begin{array}{l}20 \\
23 \\
28 \\
17 \\
12\end{array}$ \\
\hline AIDS diagnosis (31 people) & $\begin{array}{l}\text { At baseline } \\
\text { As subsequent event }\end{array}$ & $\begin{array}{l}10 \\
21\end{array}$ & $\begin{array}{l}32 \\
68\end{array}$ \\
\hline AIDS indicator illness (46 events) & $\begin{array}{l}\text { TB/KS/toxoplasmosis } \\
\text { PCP } \\
\text { Other }\end{array}$ & $\begin{array}{r}19 \\
6 \\
21\end{array}$ & $\begin{array}{l}41 \\
13 \\
46\end{array}$ \\
\hline
\end{tabular}

*Unless otherwise stated

†Includes one non-HIV related death

†TB = tuberculosis; KS = Kaposi's sarcoma; $\mathrm{PCP}=$ Pneumocystis carinii pneumonia.
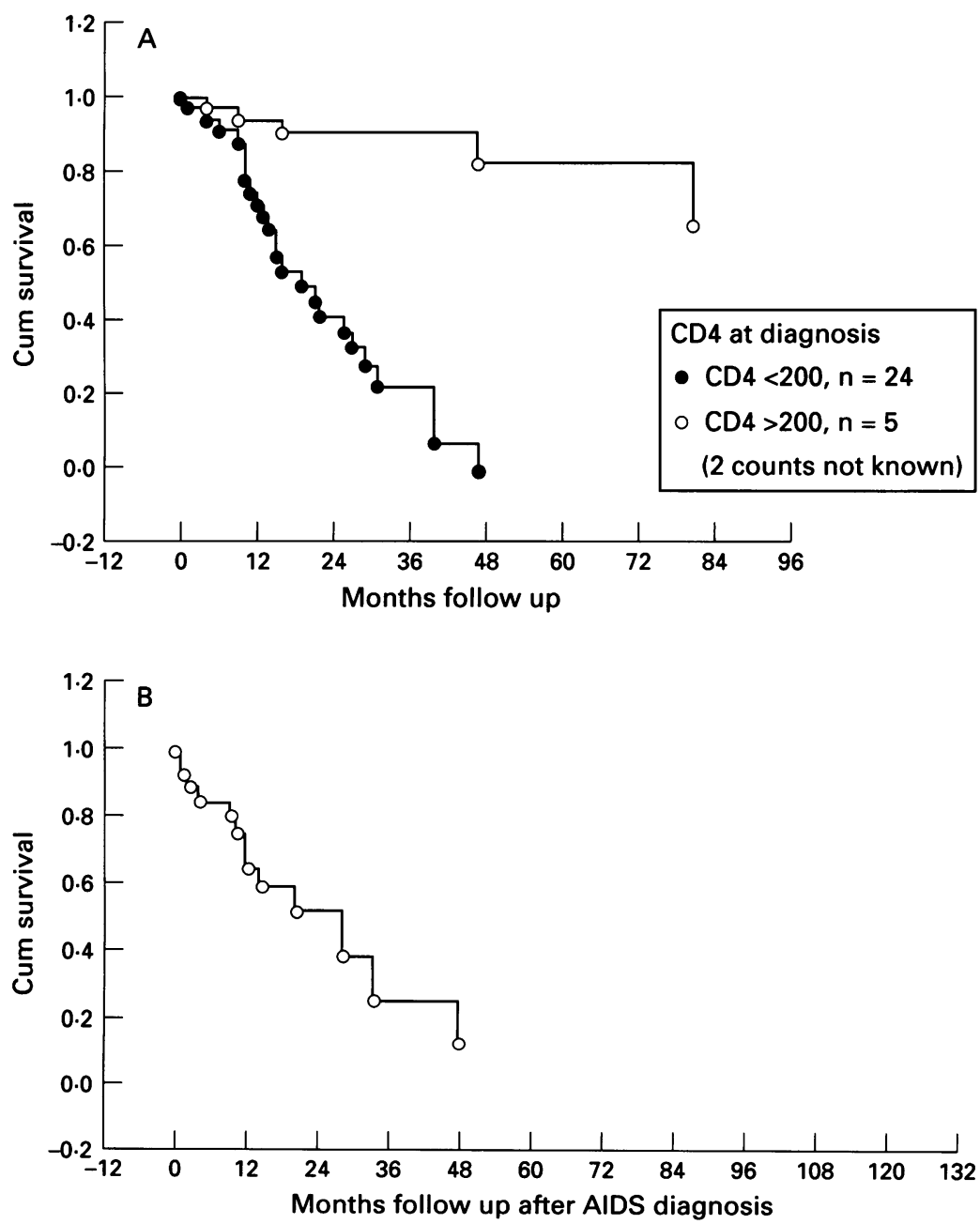

(A) Cumulative survival to AIDS defining illness, by CD4 count at HIV diagnosis. (Log rank test: $\chi^{2} 30 \cdot 89, p<0 \cdot 0001$ ). (B) Cumulative survival following AIDS diagnosis.
Meier estimates and plots. Differences in survival distributions were tested for equality using the $\log$ rank $\chi^{2}$ test. Cox proportional hazards models were then used to assess the effect of variables associated with progression to AIDS, alone, and after controlling for confounders.

\section{Results}

Ninety six patients fulfilling the case definition were followed for a mean of 21 months and provided 166 person years of experience (table 1). Vital status at 31 October 1994 was known for 76 patients (table 1). Four patients were known to have returned to their country of origin between 2 and 27 months following HIV diagnosis. Their mean CD4 count at HIV diagnosis was $129 \times 10^{6} / 1$ (standard deviation, SD $\left.97 \times 10^{6} / 1\right)$. The age and sex distribution of patients lost to follow up did not differ significantly from those for whom information was complete (data not shown).

The median duration of residence in the UK prior to HIV diagnosis was 20 (90\% range 0 to 259) months. Heterosexual intercourse was the only risk factor for HIV acquisition for 91 patients $(95 \%)$.

\section{CD4 lymphocyte counts}

The baseline CD4 lymphocyte count was available for 84 patients; median $205(90 \%$ range 20-577) $\times 10^{6} / 1$. The median CD4 count at the time of AIDS diagnosis was 25 $(90 \%$ range 18 to 359$) \times 10^{6} / 1$.

Patients over 30 years at baseline had significantly lower counts than younger subjects, $\mathrm{p}=0.0009$ (Mann-Whitney $U$ test). There was no statistically significant difference in the 
Table 2 Cox proportional hazards model of risk factors for development of AIDS

\begin{tabular}{|c|c|c|c|c|}
\hline Risk factor & $\begin{array}{l}\text { Unadjusted relative hazard } \\
\text { ( } 95 \% \text { confidence intervals) }\end{array}$ & $p$ & $\begin{array}{l}\text { Adjusted relative hazard } \\
(95 \% \text { confidence intervals) }\end{array}$ & $p$ \\
\hline \multicolumn{4}{|l|}{ Baseline CD4 lymphocyte count } & \\
\hline$<200 \times 10^{6} / 1$ & $12 \cdot 46(4 \cdot 14-37 \cdot 54)$ & $<0.0001$ & $9 \cdot 18(2 \cdot 84-29 \cdot 67)$ & 0.0002 \\
\hline \multicolumn{5}{|l|}{ Year of HIV diagnosis } \\
\hline 1991 onwards & & & & \\
\hline $1986-1990$ & $3.49(1.28-9.48)$ & 0.014 & $2.56(0.82-8.04)$ & $0 \cdot 107$ \\
\hline \multicolumn{5}{|l|}{ Age at diagnosis } \\
\hline under 30 years & 1 & & 1 & \\
\hline $30+$ years & $2 \cdot 48(1 \cdot 19-5 \cdot 17)$ & 0.015 & $1.25(0.54-2.95)$ & 0.603 \\
\hline \multicolumn{5}{|l|}{ Sex } \\
\hline female & 1 & & 1 & \\
\hline male & $1 \cdot 32(0.65-2 \cdot 69)$ & 0.440 & $1 \cdot 17(0 \cdot 52-2 \cdot 60)$ & 0.703 \\
\hline
\end{tabular}

^ Adjusted for baseline CD4 count, year of presentation, age at HIV diagnosis.

Table 3 Kaplan-Meier estimates of survival following AIDS diagnosis

\begin{tabular}{|c|c|c|c|c|c|}
\hline Factor & Median survival & $\begin{array}{l}\text { Percentage surv } \\
\text { in months (95\% }\end{array}$ & $\begin{array}{l}\% C I) \\
\text { months }\end{array}$ & $\begin{array}{l}\text { Log rank test } \\
36 \text { months }\end{array}$ & $\begin{array}{l}p \\
\chi^{2}\end{array}$ \\
\hline Overall & $20(4-36)$ & $73(55-91)$ & $25(0-52)$ & 0.04 & 0.833 \\
\hline $\begin{array}{l}\text { Year of Alds diagnosis } \\
1986-1990 \\
1991-1994\end{array}$ & $\begin{array}{l}20(10-30) \\
28(3-27)\end{array}$ & $\begin{array}{l}71(42-100) \\
73(50-97)\end{array}$ & $25(0-55)$ & 0.04 & כנסםט \\
\hline $\begin{array}{l}\text { Baseline CD4 count } \\
<200 \times 10^{6} / 1 \\
\geqslant 200 \times 10^{6} / 1\end{array}$ & $20(15-30)$ & $\begin{array}{l}63(41-84) \\
100\end{array}$ & $16(0-44)$ & $2 \cdot 48$ & $0 \cdot 153$ \\
\hline $\begin{array}{l}\text { Age at HIV diagnosis } \\
\text { under } 30 \text { years } \\
30+\text { years }\end{array}$ & $\begin{array}{l}33(2-64) \\
20(8-32)\end{array}$ & $\begin{array}{l}67(32-99) \\
59(33-86)\end{array}$ & $\begin{array}{l}33(0-83) \\
20(0-79)\end{array}$ & 1.38 & $0 \cdot 240$ \\
\hline $\begin{array}{l}\text { Zidovudine use } \\
\text { ever taken } \\
\text { never taken }\end{array}$ & $\begin{array}{l}20(10-30) \\
33(5-61)\end{array}$ & $\begin{array}{l}55(29-81) \\
77(48-100)\end{array}$ & $\begin{array}{l}23(0-58) \\
31(0-78)\end{array}$ & 0.58 & 0.446 \\
\hline
\end{tabular}

baseline counts of patients who had lived in the UK for less than one year when compared to those with a longer duration of residence, $\mathrm{p}=0.563$ (Mann-Whitney U test).

Three or more serial CD4 counts were available for 48 patients. Overall, the weighted mean decrease was $18 \times 10^{6} / 1 \mathrm{CD} 4+$ cells per year from baseline. Regression slopes showed a decline in absolute CD4 count in 32 patients, ranging from 52 to 168 cells per year and an increase, from 30 to 200 cells per year, in 16 patients. Zidovudine use did not predict an increase in CD4 count over time: $47 \%$ of patients whose CD4 count declined and 50\% whose CD4 count increased had a history of zidovudine use.

\section{Development of AIDS}

Forty six AIDS indicator illnesses (AII) occurred in 31 patients (table 1), a crude rate of 18.7 cases per 100 person years. The median time to the first AII was 40 (95\% confidence interval, CI 24 to 56) months. The spectrum of AII did not differ significantly between males and females (data not shown).

We examined whether a longer duration of environmental exposure to opportunistic illnesses common in Africa was associated with development of those diseases. Patients who developed KS, TB or toxoplasmosis had lived in Africa for a mean of 68 months longer than patients with none of these AII (95\% CI -165 to 29 months, $t 1 \cdot 45, \mathrm{p}=0 \cdot 16)$. Conversely, the mean duration of residence in the UK of those with PCP was 15.3 months longer than those without PCP (95\% CI -104 to 73 months, $t 0 \cdot 36, \mathrm{p}=0 \cdot 73$ ).

Kaplan-Meier estimates of the proportion ( $95 \% \mathrm{CI}$ ) of patients developing AIDS from the time of enrolment were: 18 (9 to 27 )\% at 12 months and 44 (30 to 58 )\% at 36 months. Survival curves for patients with baseline CD4 lymphocyte count above and below $200 \times$ $10^{6} / 1$ differed significantly (fig 1a). Different survival distributions were also noted for patients aged above and below 30 years at baseline (log rank $\left.\chi^{2} 6.37, p=0.012\right)$ and

Table 4 Comparison of survival following AIDS diagnosis between patients of sub-Saharan African origin, living in London and patients born and living in Europe

\begin{tabular}{|c|c|c|c|c|c|}
\hline \multirow[b]{2}{*}{ Reference } & \multirow[b]{2}{*}{ Location } & \multirow[b]{2}{*}{ Patient group } & \multirow{2}{*}{$\begin{array}{l}\text { Median survival in months } \\
(95 \% \mathrm{CI})\end{array}$} & \multicolumn{2}{|c|}{$\begin{array}{l}\text { Percentage surviving } \\
(95 \% \text { CI })\end{array}$} \\
\hline & & & & 12 months & 36 months \\
\hline Lundgren JD, et al. $1994^{10}$ & Europe & $\begin{array}{l}\text { Retrospective cohort. } \\
6,578 \text { people with AIDS }\end{array}$ & AIDS diagnosed 1987: 18 & $63(61-66)$ & $16(14-18)$ \\
\hline Luo $\mathrm{K}$, et al. $1995^{11}$ & Australia & $\begin{array}{l}\text { from } 1979 \text { to } 1989 \\
\text { National AIDS Registry. } \\
3,034 \text { people with AIDS }\end{array}$ & AIDS diagnosed 1989: 18 & $65(63-67)$ & $17(13-20)$ \\
\hline Osmond $\mathrm{D}$, et al. $1994^{12}$ & USA & $\begin{array}{l}\text { from } 1982 \text { to } 1991 \\
\text { Two prospective cohorts. } \\
1,496 \text { single men with }\end{array}$ & $\begin{array}{l}14 \cdot 3(13 \cdot 8-14 \cdot 9) \\
\text { AIDS diagnosed } 1986-88: 19 \cdot 1\end{array}$ & $\begin{array}{l}57 \cdot 2 \\
68\end{array}$ & $11 \cdot 2$ \\
\hline $\begin{array}{l}\text { Whitmore-Overton SE, } \\
\text { et al. } 1993^{13}\end{array}$ & UK & $\begin{array}{l}\text { AIDS from } 1983 \\
\text { Public Health Laboratory } \\
\text { Service AIDS Centre. } 3,984 \\
\text { people with AIDS from } \\
1979-91\end{array}$ & $\begin{array}{l}\text { AIDS diagnosed 1988-93: } 15 \cdot 7 \\
\text { AIDS diagnosed 1979-86:10.4 } \\
\text { AIDS diagnosed 1987-90: } 18 \cdot 3\end{array}$ & 56 & 15 \\
\hline
\end{tabular}


those diagnosed HIV positive before and after 1991 ( $\log$ rank $\left.\chi^{2} 6 \cdot 67, p=0 \cdot 0098\right)$. Patients who had lived in the UK for less than one year prior to HIV diagnosis had a similar probability of developing AIDS as those with a longer duration of residence in the UK (log rank $\chi^{2}$ $0 \cdot 19, \mathrm{p}=0 \cdot 667)$.

\section{Risk factors for progression to AIDS}

Using Cox proportional hazards regression, the relative hazard for progression to AIDS after entry into the cohort was modelled, adjusting for the factors mentioned above (table 2). Only low CD4 count remained significantly associated with progression to AIDS in multivariate analysis; the rate of progression of those with fewer than $200 \times 10^{6} / 1 \mathrm{CD} 4$ cells at HIV diagnosis was nine times that of patients with higher counts.

\section{Survival following AIDS diagnosis}

Fifteen patients died from AIDS-related conditions (table 1). This represents a crude rate of 9.0 deaths per 100 person years from the time of HIV diagnosis and 41.5 per 100 person years from diagnosis of AIDS. KaplanMeier estimates of the proportion of patients surviving following an AIDS diagnosis (fig 1b) give a median time to death of $20(95 \% \mathrm{CI} 4$ to 36) months (table 3). Table 4 shows how survival of this patient cohort compares with that observed in other populations.

\section{Discussion}

This cohort of patients of sub-Saharan African origin, constructed retrospectively from clinic records, provides information on the risk of developing AIDS and survival following a diagnosis of AIDS.

The date of HIV infection in these patients was not known. Estimates of survival time relate to the date at which HIV infection was diagnosed. Comparison with a control population from this centre was not made so we reviewed published studies to examine survival patterns of our cohort. In a large prevalent cohort of patients in the USA, ${ }^{9}$ enrolled at a similar stage of disease (defined by baseline CD4 count), the cumulative incidence of AII (31.5 to $38 \%$ after two years for subjects whose CD4 count was 200-299 $\times 10^{6 / 1}$ at enrolment) was similar to that which occurred in our patients. Progression to an AIDS indicator illness was strongly related to presentation with more advanced disease. ${ }^{9}$

Survival after the development of AIDS may be more comparable with results from other patient groups, although study design, diagnosis and management of disease may all influence results. Although this group of patients presented with advanced disease, the survival estimates were consistent with those observed in several large cohorts in Europe and North America. ${ }^{10-13}$ African patients with HIV infection diagnosed within one year of arrival in the UK presented at similar levels of immunosuppression, and had comparable sur- vival to those who had lived in the UK for longer.

It is more difficult to make direct comparisons with the survival experience of HIVinfected Africans in Africa because their level of immunosuppression at enrolment is usually unknown. Prospective studies of HIV-infected patients have shown mortality rates of $5 \%$ over 18 months in Zambia, ${ }^{14} 7 \%$ at 24 months in Rwanda $^{15}$ (women only) and 13.2 per 100 person years in Uganda. ${ }^{1}$ The greater availability of diagnostic and treatment facilities in developed countries may lead to earlier diagnosis and contribute to longer survival than that seen in Africa. These factors should be taken into account in the planning of comparative studies of survival.

HIV-infected people who move from one environment to another may manifest opportunistic diseases prevalent in the country of origin and acquire those present in the country of residence. Our finding that patients who had lived for longer in Africa prior to HIV diagnosis were more likely to have Kaposi sarcoma, tuberculosis or toxoplasmosis, and those living in the UK for longer had Pneumocystis carinii pneumonia diagnosed more commonly, is consistent with this hypothesis. The number of events was small but the observation deserves further investigation.

Retrospective analyses are liable to observer bias due to differential recording of clinical information. One fifth of all patients were lost to follow up for more than a year. The four patients known to have returned to Africa had a slightly lower mean CD4 count than those who remained in follow up which may have biased our estimates of survival upwards.

This study provides encouraging evidence that the survival experience of Africans with HIV infection residing in London is more similar to that of groups of patients born in developed countries ${ }^{10-13}$ than of those living in Africa. The lack of a relationship between duration of residence in the UK and disease progression suggests that changing conditions, such as health care provision, can have a rapidly beneficial effect on survival. Community-based HIV organisations have a vital role in increasing knowledge of, and access to, services through outreach work. Strengthening the links between out-patient services and non-statutory organisations may encourage HIV positive Africans in the community to access health services in the future. Large scale cohort studies of the natural history of HIV disease should enable comparison of the survival experience of members of different ethnic origins to further define rates of progression and clinical conditions for which appropriate surveillance, prophylaxis and treatment are required.

Dr Nicola Low is supported by a Health Services Research Training Fellowship from South Thames Regional Health Authority. Ms Katie Paine is funded by the Department of Health. Ms Rebecca Clark is funded by The Wellcome Foundation. Dr Meera Mahalingam was supported by the Joint Research Committee of King's College School of Medicine and Dentistry and South East Thames Regional Health Authority during the period of the study. 
1 Mulder DW, Nunn AJ, Kamali A, Nakiyingi J, Wagner H-U, Kengeya-Kayondo JF. Two year HIV-1 associated mortality in a Ugandan rural population. Lancet 1994 343:1021-3.

2 N'Galy B, Ryder RW, Bila K, et al. Human immunodeficiency virus infection among employees in an African hospital. N Engl $\mathcal{Y}$ Med 1988;319:1123-7.

3 Nagelkerke NJD, Plummer FA, Holton D, et al. Transition dynamics of HIV disease in a cohort of African dynamics of HIV disease in a cohort of African 743-7.

4 Seeley JA, Malamba SS, Nunn AJ, et al. Socioeconomic status, gender and risk of HIV-1 infection in a rural community in south west Uganda. Medical Anthropology Quarterly 1994;8:78-9.

5 Mbaga JM, Pallangayo KJ, Bakari M, Aris EA. Surviva time of patients with acquired immune deficiency syndrome: experience with 274 patients in Dar-Es-Salaam. East African Medical fournal 1990;67:95-9.

6 Lucas SB, Hounnou A, Peacock C, et al. The mortality and pathology of HIV infection in a West African city. AIDS 1993;7:1569-79.

7 Kreiss JK, Castro KG. Special considerations for managing suspected human immunodeficiency virus infection and AIDS in patients from developing countries. $\mathcal{f}$ Infect $D$ is 1990;162:955-60.

8 Centers for Disease Control. 1993 Revised classification system for HIV infection and expanded surveillance case definition for AIDS among adolescents and adults. $M M W R$ 1993;41:6.

9 Melnick SL, Sherer R, Louis TA, et al. Survival and disease progression according to gender of patients with HIV infection. The Terry Beirn Community Programs for Clinical Research on AIDS. fAMA 1994;272:1915-21.

10 Lundgren JD, Pedersen C, Clumeck N, et al. Survival differences in European patients with AIDS, 1979-89. BMF 1994;308:1068-73.

11 Luo K, Law M, Kaldor JM, McDonald AM, Cooper DA The role of initial AIDS-defining illness in survival folThe role of initial AIDS-defining
lowing AIDS. AIDS 1995;9:57-63.

12 Osmond D, Charlebois E, Lang W, Shiboski S, Moss A Changes in AIDS survival time in two San Francisco cohorts of homosexual men, 1983 to 1993. FAMA 1994 271:1083-7.

13 Whitmore-Overton SE, Tillett HE, Evans BG, Allardice GM. Improved survival from diagnosis of AIDS in adult case in the United Kingdom and bias due to reporting delays. AIDS 1993;7:415-20.

14 Hira SK, Ngandu N, Wadhawan D, et al. Clinical and epidemiological features of HIV infection at a referral clinic in Zambia. $₹$ Acquire Immun Syndr 1990;3:87-91.

15 Lindan CP, Allen S, Serulfira A, et al. Predictors of mortal ity among HIV-infected women in Kigali, Rwanda. Ann int Med 1992;116:320-8. 